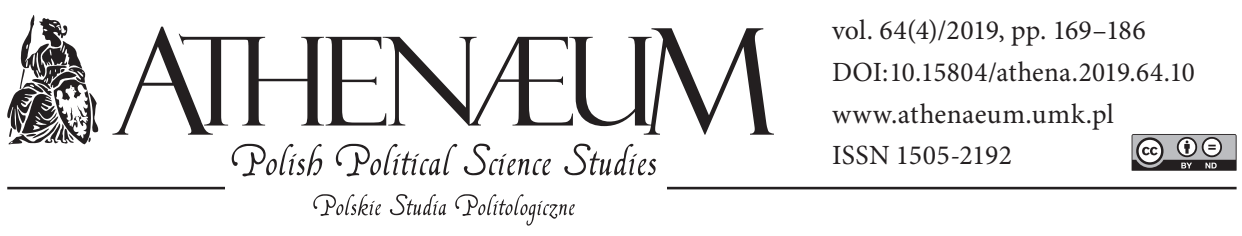

\title{
POLITICAL COMMUNICATION IN THE PERIOD OF THE CONSTITUTION REFERENDUM CAMPAIGN IN POLAND IN 1997
}

\author{
KOMUNIKOWANIE POLITYCZNE W OKRESIE \\ KONSTYTUCYJNEJ KAMPANII REFERENDALNEJ \\ W POLSCE W 1997 ROKU
}

Dominik Szczepański* 우

\begin{abstract}
- ABSTRACT
The aim of the article was to present the means of political communication in the 1997 referendum campaign in Poland, and to find answers for the following questions: 1) who was the creator of political messages?; 2) what was the ideological structure of communication?; 3) what channels did the authors of political message make use of?; 4) in what way did the recipients decode the message?; 5) what was the effect of the political messages?; 6) did the referendum campaign influence the result of parliamentary elections - and if so, to what degree?

The answers acquired in that way will contribute to exposing full perspective of political communication.
\end{abstract}

Keywords: political communication; constitution referendum; campaign; political parties; constitutional coalition; anti-constitutional block; president
Celem artykułu było ukazanie sposobu komunikowania politycznego podczas kampanii referendalnej w Polsce w maju 1997 roku oraz uzyskanie odpowiedzi na następujące pytania badawcze: 1) kto był kreatorem komunikatów politycznych?; 2) jaka była kompozycja ideowa komunikatu?; 3) jakimi kanałami posługiwali się autorzy komunikatów politycznych?; 4) w jaki sposób odbiorcy dokonywali odkodowania przekazu?; 5) jaki skutek wywołały nadane komunikaty polityczne?; 6) czy i w jakim stopniu kampania referendalna miała przełożenie na wynik wyborów parlamentarnych?

Uzyskane w ten sposób odpowiedzi przyczynią się do poznania pełnego obrazu komunikowania politycznego.

Słowa kluczowe: komunikowanie polityczne; referendum konstytucyjne; kampania; partie polityczne; koalicja konstytucyjna; blok antykonstytucyjny; prezydent

* University of Rzeszow, Faculty of Sociology and History. 
According to the definition provided by Stanisław Michalczyk, political communication should be understood as "the process that relies on information exchange between political leaders, media and citizens, concerning events and affairs that take place in the range of public politics" (Michalczyk, 2005). Such perspective of communication implies that we are dealing with bilateral character of the relation that can undergo within the triad that encompasses: 1) political elites, 2) citizens-voters, and 3) media that serve an indirect role in this process and serve to transmit information (Garlicki, 2010).

The players are politicians and citizens (public opinion), and between them there is the third group, i.e., the media (Ulicka, 1996). The entities that communicate between each other participate in a permanent communication process that takes place according to fixed rules of legal, moral and custom character (Marciniak, 2012). Those entities also have certain tasks to fulfil, large part of which can be described as common (e.g., political socialization, informing and forming opinions on current political affairs), but also separate and complementary (e.g., "media present the offer of the political parties, set the importance hierarchy of public issues, reinforce the relation between politicians and citizens; media and public opinion can legitimize the activities and decision of the authority, and the politicians themselves, by means of communication activity, form the image of politics, explain political decisions, share opinions with the society" [Marciniak, 2012]).

This complementarity was visible during the constitution referendum campaign in Poland in May 1997, which was a result of Polish MPs preparing a new basic law (Chruściak \& Osiatyński, 2011). The constitution, which was passed on $2^{\text {nd }}$ April 1997, required, according the Law of 23 ${ }^{\text {rd }}$ April 1992 on the procedure for preparing and enacting a constitution of the Republic of Poland, together with later amendments, social ratification in a nation-wide referendum, which was appointed by President Aleksander Kwaśniewski on 25 ${ }^{\text {th }}$ May 1997. Considering the fact that approval of voters, expressed in a voting act, is a necessary element in the process of enacting constitution, the referendum has to be classified, thus, as on obligatory one (Repel, 1997).

When focusing primarily on the essence of the institution of referendum, it must be noted that it was (and still is) a direct form of participation of citizens in the public life. In Poland, especially after 1989, a nationwide referendum was seldom implemented and concerned mainly polls in 1996, 1997, 2003, and 20151.

1 During the Polish People's Republic, the institution of referendum was rarely used. The first one was held on 30th June 1946, as a result of which the communists paved the way for the establishment 
There have been many more local referendums, the subject of which was, among others, recalling an organ comprising a unit of municipal government before the end of its term, or self-taxation of citizens (Piasecki, 2005; Sękowska, 1996). As far as the range of the term referendum is concerned, it can be defined, most generally, as "the system form that ensures direct decision-making of voters, by means of voting, about different issues of the public life (concerning a country or a particular territory) being the subject of voting (e.g., constitution, standard laws, etc.) and with the effectiveness indicated in the voting act" (Musiał-Karg, 2008; Rytel-Warzocha, 2011).

The initiators, and then supporters or opponents of holding a particular referendum were, in general, political parties. An exception, in this regard, was the referendum to approve constitution. From the perspective of party interests it was treated as an instrument more needed by the parties than voters who were driven, to a large extent, by the trust toward main parties of the political struggle.

This instrumental treatment of the institution of referendum by the political parties was nothing else than down-to-earth calculation of potential gains and losses, estimated and dependant both on current political situation, real possibilities of weakening political competitors, the level of inner-party conflicts, and the perspective of consolidating the public opinion.

\section{THE CONSTITUTION REFERENDUM - CAMPAIGN BEFORE THE CAMPAIGN}

Formal commencement of the referendum campaign was a pre-campaign before the upcoming parliamentary elections ${ }^{2}$. In its course there occurred instances of public presentations of candidates running for a post of MP or a senator, or informing the society about the party congresses held. This period was also preceded by consolidation processes at the political stage, in result of which new political bodies were formed.

of a political system in Poland based on the hegemony of one party, while the second one was held on 29th November 1987 and was related to the second stage of the reform which saved the socialist economy (Siedziako, 2018; Dudek, 2004).

2 Work on the constitution in the years 1993-1997 took place under certain political conditions. The Sejm majority was held by post-communist groups, which had 376 seats in the National Assembly, which gave them the required two thirds of the votes to vote on the constitution (Tomaszewski, 2007; Kowalczyk, 2016). 
These factors contributed to enlivening the discussion on the character of the referendum itself, including mobilisation of own electorate and undecided voters. A party that also participated in the referendum campaign was the Catholic Church, the expression of which were statements of the Polish Episcopal Conference, commenting current affairs in the country and presenting the official stance of clergy towards the discussed issue (Piasecki, 2005).

The choice of the constitution referendum date was preceded by a dispute of tactical nature. The Democratic Left Alliance [Sojusz Lewicy Demokratycznej - SLD] - Polish People's Party [Polskie Stronnictwo Ludowe - PSL] coalition that held power at that time suggested holding constitution referendum simultaneously with the parliamentary elections planed for September 1997, which was met with a positive response of, among others, the deputy head of the PSL parliamentary club, Aleksander Bentkowski, who claimed that it would lead to saving a lot of organisational expenditures and, therefore, increase the turnout. In reality this meant a sociotechnical action based on the intention to make use of the supporters of passing the constitution, who probably would vote in the elections for the government coalition parties. There also appeared the second idea connected with appointing the date of referendum for June 1997, which would overlap with the pilgrimage of Pope John Paul II to Poland. The leaders of main political powers, especially Union of Freedom (Unia Wolności - UW), were afraid of polarisation of the Polish political stage and its division into two opposing blocks. The politicians of the Labour Union (Unia Pracy - UP), who actively got involved in modifying the project of concordat, or the leaders of PSL, who despite forming the governmental coalition with SLD emphasised their own contribution into preparation and passing the new constitution, had similar thoughts (Szamik, 2016; Sieklucki, 2006).

According to the Law of $29^{\text {th }}$ June 1995 on referendum, the campaign was set 20 days before the day of voting. In paragraph 38 of this act it is stated: "referendum campaign serves to present and explain, by the institution holding the referendum and the State Election Commission [Państwowa Komisja Wyborcza], respectively, the content of questions and variants, as well as problems put to vote, and presenting the stances of political parties, non-governmental organisations and other entities concerning the issue referred to by the referendum" (Ustawa..., 1995). Due to the above, both supporters and opponents of passing, by means of referendum, the new constitution had 180 minutes of airtime in the public $\mathrm{TV}$, as well as 240 minutes in the public radio (Rozporzadzenie Krajowej Rady Radiofonii i Telewizji..., 1994). 
Detailed information on the use of the airtime was provided by the report of the National Broadcasting Council [Krajowa Rada Radiofonii i Telewizji] on the annual period of its activity, in which it was indicated that only $7 \%$ of the airtime in TVP (24 minutes) was dedicated to special broadcasts devoted to the issues of the referendum procedure (voting procedure, registers, lists of voters, or certificates on the right to vote). Most airtime was devoted to the auditions of the National Broadcasting Council, which comprised, in total, approximately 93\%, as well as proclamations of the President of the Republic of Poland. With regard to radio broadcasts, the proportions were identical (Monitoring konstytucyjnej kampanii referendalnej..., 1998). The remaining airtime was used by the political parties and other entities in order to present their own political formations and their programs, which indicated objectification of the institution of referendum and the citizens.

A separate category was the form of explaining the issues of referendum by the political actors taking part in the campaign. The formula of short, threeminute TV broadcasts turned out to be a significant obstacle, as the politicians representing opposing political options who appeared in them caused unnecessary chaos and information pollution. The same thing concerned presentation of particular content of the subject of the basic law regulation. This situation did not, however, concern radio broadcasts in which the listeners were informed and provided with specified information on the subject of discussion and what the statements of politicians concerned. Limiting too much the airtime turned out to be a drawback in running a fully professional information campaign. In reality it may be said that such behaviour of politicians did not comprise an argument encouraging the voters to take part in the referendum, and, therefore, did not increase the interest in the referendum campaign.

\section{CONSTITUTIONAL COALITION}

The referendum campaign comprised an intense political struggle characterised by frequent tensions between supporters and opponents of the new constitution. The then-division of the political stage did not go along the traditional left-right division line, or the post-communist and post-solidarity groups (Tomaszewski, 2007). The constitutional coalition, as well as the anti-constitutional opposition were formed by the groups coming from different ideological groups. 
The supporters of passing the constitution were: UW, UP, PSL, SLD, National Party of Retirees and Pensioners [Krajowa Partia Emerytów i Rencistów KPEiR], Polish Socialist Party [Polska Partia Socjalistyczna - PPS], as well as the President of Poland, whose information activity was clearly noticeable in the TV and radio broadcasts. An additional argument for the activity of A. Kwaśniewski for passing the new constitution was sending to Polish households almost 11,5 million copies of the basic law, which also included a letter from the President encouraging the citizens to support the constitution in the upcoming referendum.

In the case of political parties that were both in the coalition as well as opposition, we can speak of a relatively boring, although occasionally very aggressive referendum campaign. Financial savings were the dominant topic - perhaps due to the upcoming parliamentary elections. This was visible in the form of a low number of information posters and party materials. The debates that took place were characterised by a lack of vigour and arguments for passing the constitution, as well as disputes presented in the press, including party and union press.

With regard to the activity of the UW, group one should emphasise that both in the rhetoric of party leaders as well as in numerous documents, the contribution of the party in preparing and enacting the constitution was emphasised (Szczepański, 2013, 2014). Emphasizing convergence between the constitution of the Republic of Poland with the project of the basic law handed in by the parliamentary club of the Democratic Union (Unia Demokratyczna - UD) in 1994, or the fact of reporting the preamble by Tadeusz Mazowiecki, which was, by the way, passed by the National Assembly ${ }^{3}$, can serve as examples. As presented by the publishing houses, T. Mazowiecki was called "the father of the new constitution". When asked about that, Mazowiecki stated: "if I answer that I feel I am the father, then one may think that I am conceited, and if I answer that I am not, then some may think that I distance myself from this constitution" (Artymowski, 1997).

An additional activity undertaken by UW was founding, in the middle of April 1997, an Advisory Committee of UW on the constitution, together with

3 The author of the preamble proposed by Tadeusz Mazowiecki was a publicist of "Tygodnik Powszechny", Stefan Wilkanowicz, who in 1996, in the abovementioned newspaper, published the article Moja prywatna preambuła. The text of this preamble was handed over to T. Mazowiecki by the Head of the Polish Episcopal Conference - bishop Tadeusz Pieronek. The final version of the preamble passed by the National Assembly was a result of backstairs discussions and talks held by the leader of UW with Marek Borowski from SLD (Borecki, 2007). 
Ewa Łętowska, Henryk Samsonowicz, Kazimierz Kutz, Krzysztof Pawłowski, and Andrzej Wajda. Its members included "persons of universal respect and authority", and the aim of this committee was encouraging the citizens to take part in the referendum and to vote for passing the constitution (Komitet Doradczy..., 1997). Apart from that, since the beginning of January to the end of April 1997, UW was issuing unrelated prints entitled Co zrobiliśmy, by konstytucja była lepsza [„What we did to make constitution better”], in which the presented statements were used in the referendum campaign (Co zrobiliśmy..., 1997).

In the issued leaflet, UW informed about what the constitution was providing Poland and all the Poles with. Apart from considering a range of rights and civil liberties the authors of the leaflet pointed to constitutional guarantees, such as equality before the law, protection of the institution of marriage understood as a relationship of a man and woman, or the opportunity to submit a complaint into the Polish Constitutional Tribunal by a citizen if his or her rights were violated. The supporters of UW were making use of the authorities, e.g., Leszek Balcerowicz, Hanna Suchocka, Janusz Onyszkiewicz, and Jan Nowak Jeziorański (Referendum konstytucyjne..., 1997). In the summary of the referendum campaign, compiled by the electoral team of UW, it was stated that politicians of UW"were speaking with one voice" about the constitution, whereas in the party bulletin the undertook effort was assessed in the following manner: "finally, after seven years, the works on the new basic law ended with success. The foregoing political quick fix has passed in perpetuity. Despite the campaign that has been crude, deceitful and deprived of logical arguments on the part of constitution opponents, the greater part of society which voted was in favour of the constitution passed on $2^{\text {nd }}$ April by the National Assembly. [...] We, the Freedom Union, have a particular reason to be content. [...] The Union not only supported the constitution, but it also co-created it. Tadeusz Mazowiecki is called by the press 'the father of the constitution' for a reason" (Golański, 1997).

Noticeably smaller engagement was observed among the UP community. The party MPs in the Sejm of the $2^{\text {nd }}$ term submitted the initiative of constitution referendum, they were against passing the concordat and were also for separating the Church from the state. In the prepared handout entitled Konstytucja Twoich Praw TAK dla nowej Konstytucji [Constitution of Your Rights. YES to the New Constitution], the leaders of UP emphasised that adopting the new basic law will comprise a pass to join united Europe and support for the state that is „1) safe, independent and sovereign, 2) democratic and law-abiding, 3) guaranteeing citizens' rights and liberties, 4) fair for all the citizens, 5) efficiently organised 
and ruled, 6) valuing its own tradition and culture" (Konstytucja Twoich Praw..., 1997).

The handout also emphasised the contribution of UP in the enactment process of the Constitution of the Republic of Poland. This also concerned the provisions regarding social rights (important for people of low income, including students), as well as the provision of free education (Kostrzębski, 1997). In the rhetoric of UP leaders the constitution opponents were discredited. It was put as "do not trust opponents of the constitution, calling for its rejection. Do not let Poland, which was the first to liberate from communism, to remain, as the only country, with constitution regulations from the times of Stalin" (Konstytucja Twoich Praw..., 1997). This statement was addressed to the groups concentrated around the Solidarity Electoral Action of the Right (Akcja Wyborcza Solidarność - AWS), and the Movement for Reconstruction of Poland (Ruch Odbudowy Polski - ROP), calling for rejecting the constitution in the referendum.

Similar activity was demonstrated by PSL. The agrarians were in favour of remaining the Senate in the foregoing form. The regulations concerning, among others, free healthcare and free education, or the Polish language as the official one, were introduced (Urbaniak, 1997). In the Resolution No 6 of the Chief Council of PSL Concerning the Standpoint of PSL Towards the Enacted Constitution and the Constitution Referendum, utter respect was expressed to the MPs and Senators of PSL for their contribution and work on the new constitution, especially for introducing to it references to God and Nation, emphasizing Christian and cultural heritage, or introducing the institution of family farm as the basis of the state agrarian system (Rezolucja $n r$ 6, 1997; Ludowcy w Sejmie..., 1997). PSL was encouraging to take part in the referendum only in party documents, while during the referendum campaign the leaders of PSL distanced themselves from the constitution, which was incomprehensible to public opinion, especially because PSL was perceived as one of the co-authors of the new basic law (Pastuszka \& Machynia, 1997).

Unlike PSL, the leaders of SLD had a different approach to the issue of referendum. In numerous party resolutions, Social Democracy of the Republic of Poland (Socjaldemokracja Rzeczypospolitej Polskiej - SdRP) emphasized the importance and necessity of passing the new constitution (Uchwała Rady Naczelnej Socjaldemokracji..., 1997; Uchwała Rady Naczelnej SdRP..., 1997). What was not present in the party rhetoric was significant compliance towards PSL and UW regarding the issues of passing particular wordings of the constitution, which was 
treated as a form of a historical compromise being the highest political priority (Sosnowska-Materska, 2006). Pertaining to the constitution referendum, the leader of SdRP, Józef Oleksy, wrote: "the compromise arrangements concerning disputed wordings were determined by the feeling of responsibility for Poland. Party disputes were off the radar" (List przewodniczacego Socjaldemokracji..., 1997). Apart from justifying a wide range of constitution rights and guarantees, the leader of SdRP appealed to the party members, voters and all the citizens to participate in the referendum on passing the constitution.

An important agitation-informative role for passing the basic law by the nation was played by the "Trybuna" newspaper, where representatives of SLD and UP used to present their comments. A separate category were arguments and disputes of renown figures connected with the left, including the interviews with the head of state. Attacks of the representatives of AWS and ROP on the president were commented, especially for his participation in the information campaign, which was recognized by PKW [State Election Commission] as acceptable due to lack legal regulations forbidding the president running a campaign for voting in a referendum (Wąsik, 1997).

The least information on the means of political communication is available in the case of KPEiR and PPS. According to Antoni Malinowski, Piotr Ikonowicz - the leader of PPS - was in favour of passing the new constitution through a referendum, which was determined mainly by the possibility of weakening the monopoly of the right wing for patriotism. The axis of the dispute was not the basic law content, but its "authorship between the democratic constitutional group and the non-parliamentary anti-constitutional group" (Malinowski, 1997). Due to the above, P. Ikonowicz came to the conclusion that right-wing groups, such as ROP or "Solidarity” concentrated around AWS, called for the catholic constitutional order and to win they had to form an alliance with the Catholic Church that involved the whole clergy. The leader of PPS claimed that the result of the constitution referendum would not influence results of the parliamentary elections. The successors of the referendum success were supposed to be, in his view, only the parties responsible for passing the constitution, and SLD in particular. Therefore, PPS considered passing the constitution in the referendum as essential, as it would enable to weaken the right side of the political stage. 


\section{THE ANTI-CONSTITUTIONAL GROUP}

Most postulates and arguments against passing the constitution, which were provided by the anti-constitutional group, were of general character. The opposition was formed by: AWS supported by the Civil Committee for Saving Poland, ROP, Non-partisan Support for Reforms [Bezpartyjny Blok Wspierania Reform - BBWR], Confederation of Independent Poland [Konfederacja Polski Niepodległej - KPN], Conservative Coalition [Koalicja Konserwatywna - KK], Real Politics Union [Unia Polityki Realnej - UPR], and the Catholic Church as an entity strictly cooperating with AWS. One may also include in the anticonstitutional group the Civil Movement for Uninominal Electoral Posts, whose activity in the campaign period contributed to the agitation discrediting the basic law passed on $2^{\text {nd }}$ April 1997.

A wide electoral coalition, which was AWS, called for rejecting the constitution in the referendum in a decisive manner. The reason for that was the idea conceived within that group that relied on integrating the post-Solidarity groups, emphasizing "an alternative program of working for Poland" (Piasecki, 2005). The second important reason was rejecting by the Sejm - within the minority proposals - a civic project of constitution prepared by "Solidarity" (Dabertowa, 2005). Within AWS it was thought that if the basic law passed did not include any of the postulates included in the civic project, then the referendum was to be boycotted. Several days later, M. Krzaklewski changed his mind and was encouraging to take part in it and to vote for rejecting the constitution (Czas na akcje..., 1997). Additionally, AWS acted against the president, accusing him of direct agitation for passing the constitution by the nation, which, in consequence, led to filing a protest to PKW by M. Krzaklewski. He meant not only the agitation itself, but also the letter of the president sent to over 11 million citizens for the money of taxpayers (Tomaszewski, 2007).

The referendum campaign of AWS was run parallel in two ways. The first one was at the central level and concerned directly the initiatives undertaken by M. Krzaklewski. The next example was presenting the constitution in the worst light, and passing it in the referendum was treated as "Bolshevik storm". In the appeal issued already in April 1997, Independent Self-Governing Trade Union “Solidarity” (Niezależny Samorządny Związek Zawodowy „Solidarność” - NSZZ "Solidarity") announced that enactment of the constitution can be reverted "only with the effort of the whole nation, such as the Bolshevik invasion was countered in 1920. Similarly like then, it is necessary to appeal to the divine 
providence and enthrone the Christ in the name of the Polish Nation. The date of the referendum was also supposed to be symbolic as it coincided with the $46^{\text {th }}$ International Eucharistic Congress in Poland. They called then to enthrone the Christ so that he would support the efforts of patriots in rejecting the constitution" (Tomaszewski, 2007).

The second way referred to individual activities of AWS members. Those were referred to, in a special way, by the Civil Committee for Saving Poland, whose representative was Krystyna Czuba, who was also in charge of the AWS committee for media. She was the author of the brochure entitled Project of the New Constitution against Poland, for Dechristianising and Partitions of Poland, in which she alleged that passing the constitution was a threat, among others, to introduce atheism (Art. 53, Para. 5), losing sovereignty (Art. 90), deprivation of child custody (Art. 48), preserving political dominance by the post-communists (the statement concerning proportional representation, Art. 87, para. 1), and that the president would hold unlimited power, exercising tyranny (Art. 134, Para. 3) (Projekt Nowej Konstytucji..., n.d.). When analysing the information presented in the brochure, one should consider that majority of the postulates indicated lack of understanding of the basic law content or its superficial reading. The intention of the brochure was to discredit the constitution.

Many issues addressed by AWS were also addressed by ROP. This concerned the protests against the President of Poland. ROP involved in collecting 250 thousand signatures under the petition to carry two projects of constitution to referendum voting - one passed by the National Assembly, and the second one - a civic project. While ROP presented an uncompromising stance towards any constitution compromise, AWS remained unambiguously silent and procrastinated with adopting a position. For Jan Olszewski the situation meant "a compromise between faith in God and atheism" (Malinowski, 1997). Due to this fact, ROP stated: "In the referendum of 25 May say NO to them - because Poland is not for sale" (Tomaszewski, 2007). The party, as the only one in the whole campaign, presented the most substantive arguments. These were, among others, providing the possibility, without a consent on the part of the Polish nation, to transfer the authority to an undefined international organisation (Art. 90, Para. 1, and Art. 91, para. 3); freeing the government from a concern for the state economic circumstances and living conditions of people (Art. 146, Para.4); depriving the government and Sejm of the influence on the value and power of the Polish currency, passing the control over it to the Monetary Policy Council (Art. 227, Paras. 5-6); preserving the proportional representation (Art. 
96, Para. 2); disenabling independent upbringing of children (Art. 48, Para. 1, Art. 53, Para. 3) (Dudek, 2007; Tomaszewski, 2007; Podgórzańska, 2004). Similar arguments were present in the leaflets made by ROP, which were dominated by demagoguery. As noticed by Tomasz Słomka (1997), "the criticism had no reflection in the real content and philosophy of the constitution being the subject of voting in the referendum".

Slightly smaller activity was demonstrated by other parties, namely BBWR, KPN, KK, and UPR. Those parties, except KK, claimed that there was no need or basis for a constitution compromise. In the handouts it was indicated in a general way that the voters should not vote for passing the constitution. These were arguments indicating the possibility to lose sovereignty (Art. 90), creating a threat to state security, preserving system and economic dysfunctions, lack of protection of property of State treasury (Art. 218), questioning parental authority, forcing citizens to compulsory military service, or giving power to party institutions (proportional representation) (Komunistycznej Konstytucji..., 1997). For the conservative liberals from UPR, the basic law included too many negative statements rather than positive ones. This also concerned the civic project, which was commented on by the leader of UPR, Janusz Korwin-Mikke, in a negative manner. In his view, both documents preserved "socialism" and "syndicalism" (Borowik, 2011).

The politicians of KK had a different approach towards the issue of constitution and participation in the referendum. Aleksander Hall claimed that the basic law passed in April 1997 comprised a constitution of four political parties and was their constitution "from top to bottom". He also claimed that voting for the constitution was a choice that was harmful to Poland (Borowik, 2011). This politician also stated: "There is a constitution. It does not satisfy me; not because it was passed by a parliament dominated by the left, but for substantive reasons. It deserves, however, serious reflection. The decision on what to do in the constitution referendum should be made in a mature way. The emotions that accompany the constitution debate are a bad advisor" (Hall, 2000). Almost 20 years after those events this politician stated: “On $25^{\text {th }}$ May, I voted for rejecting the constitution [...]. With hindsight, I think that it ended up well. Despite its weaknesses (I have not changed the opinion on them), the constitution of 1997 was a big step in a good direction, when comparing with the previous legal situation. The time of system quick fix was ended. It is highly doubtful whether the parliament of the next term would be able to pass it" (Hall, 2011). 
A significant role in the period of the referendum campaign was played by the Catholic Church, especially the Council of the Polish Bishops' Conference. It expressed its stance already on $16^{\text {th }}$ January 1997 , in which it referred to the axiological level of the basic law. The Council decided that one could not "include in the constitution a statement recognising it as the highest law in the country in the absolute sense, and recognise the man as the highest lawmaker" (Delong, 2016). The bishops, on the other hand, paid attention to the reduction of the sources of human rights, in particular the paragraph on the protection of human life, recognising only marriages of people of different sexes and duties resulting from it - religious and moral upbringing of offspring. Therefore, the presence of the Catholic Church during the referendum campaign was seen in the form of support provided to the parties and coalitions in the anti-constitutional block. As it was put by Marek Delong, "the bishops clearly opted for one of the sides of the constitution dispute, while in September they remained reticent in articulating their political preferences" (Delong, 2016). An accurate evaluation of the participation of Catholic Church in the referendum campaign was indicated by Roman Graczyk. He stated that this role was destructive, which could be noticed in the form of numerous instances of ignorance and blindness on the part of the Church. He also claimed that "one must conclude, regretfully, that the Church involved in the issue that it was not particularly competent about, and even turned out to be remarkably incompetent. It fought against the constitution that was far better than both the regulations that were then in force, as well as the civic project supported by 'Solidarity' and then AWS" (Graczyk, 2000). Thus, one needs to conclude that in the case of the Catholic Church and its participation in the referendum campaign, the dispute over the constitution was characterized by too excessive emotional load and exaggerated political expression, which caused confusion of the public opinion (Kowalczyk, 2016).

In the case of the representatives of the Civil Movement for Uninominal Electoral Posts, the stance against passing the constitution in the referendum was opted for. The main arguments that were used were "NO to proportional constitution", "NO to proportional representation", "Enough with party cheating!", "Enough with party corruption", "Enough with party-proportional constitution!" (Dlaczego „NIE”..., 1997). The argumentation provided the information that the constitution preserves the authority of people "handed over by the collapsing communist empire. We want Poland to finally have a chance to choose its own, authentic political elite. Such a chance would be provided by the plurality voting system, hence the one based on the single-member constituencies" (Dlaczego 
„NIE”..., 1997). The second of more important postulates presented in the basic law was getting rid of national lists and introducing instead 460 single-member constituencies. One should add that in the period of the referendum campaign the movement repeated its appeal to the society.

\section{REFERENDUM RESULTS AND FINAL CONCLUSIONS}

On $25^{\text {th }}$ May 1997, the fate of the new constitution was resolved. The voter turnout on this day was just $42.86 \% .52 .71 \%$ of citizens voted for the constitution, and $45.89 \%$ of the votes were against it. There were 170,000 invalid votes. Almost two months later, the Supreme Court dismissed the AWS applications for annulment of the referendum result. As emphasized by A. Piasecki, this application had a propaganda and symbolic meaning, because its groundlessness resulted directly from the 1995 referendum act (Piasecki, 2005; Dudek, 2007).

Several conclusions can be made when assessing the referendum campaign. First of all, the campaign was an example of failed mobilization of electorates of individual political actors. Secondly, the weakness of both the constitutional coalition and the anti-constitutional block was noticeable, characterized by the fact that both blocks had no idea how to convince voters that their decision - for or against the constitution - had any meaning for the state. Thirdly, representatives of political actors mistakenly assumed that the citizens, along with receiving the text of the Basic Law, would read and understand it. It was also wrong to discuss the content of articles by politicians without a specific indication of what the record is about (applies to television broadcasts). Fourthly, the marginal leaflet and poster campaign contributed to the poor voting result. And finally, political actors used the period of the referendum campaign to run a campaign related to elections to the Sejm and the Senate.

Responding to the questions set out in the introduction, it should be noted that the creators of political messages were political actors (the President of the Republic of Poland, political parties, and coalition committees), trade unions, social movements, as well as the Catholic Church. The composition of the ideological message consisted of the following elements: 1) television statements; 2) radio messages; 3 ) newspaper articles; 4) party materials (including leaflets, posters, emblems, programs and acts); 5) dialogue of politicians with citizens and voters during numerous meetings. The most frequently used transmission channels were: 1) traditional media, i.e., television, radio, and press; 2) own media 
of political actors (party and trade publications, etc.); 3 ) meetings of politicians with voters and the happenings organized in this way; 4) the use of ambo by the clergy as a place of agitation against the enactment of the constitution.

Doubts may arise from answering the question about the effect of political messages, because the result of the referendum showed that the social response to political communiqués was feeble. In the referendum itself, inefficiency was visible in the area of political communication dictated by the lack of proper political communication, lack of determination of the right voter (mainly referred to as so-called undecided voters) and lack of skills to overcome own limitations (mainly referred to the above-mentioned actors involved in the referendum campaign), stereotypical thinking and rising above party (political) divisions. Answering the last of the questions, it should be stated that the parties in the constitutional coalition lost in the parliamentary elections, the exception in this regard was the UW, which formed a coalition with the AWS after the winning elections. In the case of the anti-constitutional block, only the AWS succeeded, which immediately before the elections called to create the post-August Polish camp that could remove the SDL-PSL coalition from power.

After the parliamentary elections in 1997, the parties and entities calling for the rejection of the constitution accepted the current state of affairs and did not take any action to change the Basic Act. The AWS postulate from the period of the referendum campaign, which dealt with the superiority of the civic project over the constitution of $2^{\text {nd }}$ April 1997, and the possible change of the constitution if AWS gained power, might have seemed surprising. The political practice of 1997-2001 almost completely revised this idea.

\section{REFERENCES:}

Artymowski, J. (1997). Akt zgody: rozmowa z Tadeuszem Mazowieckim. Warszawski Biuletyn Informacyjny Unii Wolności, 4.

Borecki, P. (2007). Kompromis końca wieku: klauzule wyznaniowe Konstytucji z 1997 r. Res Humana, 2, 11-15.

Borowik, B. (2011). Partie konserwatywne w Polsce 1989-2001. Lublin.

Chruściak, R., \& Osiatyński, W. (2001). Tworzenie konstytucji w Polsce w latach 1989-1997. Warszawa.

Co zrobiliśmy, by konstytucja była lepsza (1997, April 4). Druk Unii Wolności. Warszawa. Czas na akcję. Marian Krzaklewski w rozmowie z Maciejem Łętowskim i Piotrem Zaręba (1997). Warszawa: Tysol. 
Dabertowa, E.R. (2005). Od „drużyny Lecha Wałęsy” do Akcji Wyborczej Solidarność: „Solidarność" w parlamencie (1989-2001). Poznań.

Delong, M. (2016). Konferencja Episkopatu Polski wobec wybranych kwestii politycznych $i$ społecznych $w$ Polsce $w$ latach 1989-2014. Rzeszów.

Dlaczego „NIE” dla tej konstytucji (1997, March 23). Druk ulotny Obywatelskiego Ruchu na rzecz Jednomandatowych Okręgów Wyborczych. Kraków.

Dudek, A. (2004). Reglamentowana rewolucja: rozkład dyktatury komunistycznej $w$ Polsce 1988-1990. Warszawa.

Dudek, A. (2007). Historia polityczna Polski 1989-2005. Kraków.

Garlicki, J. (2010). Komunikowanie polityczne - od kampanii wyborczej do kampanii permanentnej. Studia Politologiczne, 16(1), 26-45.

Gebethner, S. (1997). Referendum konstytucyjne - uwikłania społeczne i prawnoustrojowe. In: M.T. Staszewski (ed.). Referendum konstytucyjne w Polsce (pp. 93-143). Warszawa: ISP PAN.

Golański, R.A. (1997). Jest Konstytucja! Warszawski Biuletyn Informacyjny Unii Wolności, 5 .

Graczyk, R. (2000). Czy religia służy demokracji. Tygodnik Powszechny, 2.

Hall, A. (2000). Widziane z prawej strony. Bydgoszcz: Światowid.

Hall, A. (2011). Osobista historia III Rzeczypospolitej. Warszawa: Rosner i Wspólnicy.

Komitet Doradczy Unii Wolności o Konstytucji (1997, April 28). Warszawa.

Komunistycznej Konstytucji z 2 kwietnia 1997 r. NIE (1997, May). Druk ulotny UPR. Wrocław.

Konstytucja Twoich Praw TAK dla nowej Konstytucji (1997, May). Druk ulotny Unii Pracy. Warszawa.

Kostrzębski, K. (1997). Unia Pracy - między zabiegami o przetrwanie na scenie politycznej a poszukiwaniem tożsamości. In: S. Gebethner (ed.). Wybory'97: partie i programy wyborcze (pp. 180-200). Warszawa: Elipsa.

Kowalczyk, K. (2016). Między antyklerykalizmem a konfesjonalizacją: partie polityczne wobec Kościoła Katolickiego w Polsce po 1989 roku. Toruń: Wydawnictwo Adam Marszałek.

List przewodniczacego Socjaldemokracji Rzeczypospolitej Polskiej do członków partii (1997, May). Warszawa.

Ludowcy w Sejmie II kadencji (1993-1997 r.) (1997, July). Warszawa: Biblioteka Klubu Parlamentarnego PSL.

Malinowski, A. (1997). Instytucja referendum konstytucyjnego w odbiorze społecznym. In: M.T. Staszewski (ed.). Referendum konstytucyjne w Polsce (pp. 145-188). Warszawa: ISP PAN.

Marciniak, E.M. (2012). Komunikowanie polityczne w ujęciach interpretacyjnych. Studia Politologiczne, 25, 13-30.

Michalczyk, S. (2005). Komunikowanie polityczne. Teoretyczne aspekty procesu. Katowice: Wydawnictwo Naukowe ŚLĄSK.

Monitoring konstytucyjnej kampanii referendalnej 1997. Załącznik do Sprawozdania Krajowej Rady Radiofonii i Telewizji z rocznego okresu działalności (1998). War- 
szawa. Retrieved from: http://www.krrit.gov.pl/Data/Files/_public/Portals/0/ sprawozdania/spr1998/spr1998_zal_referendumkonstytucyjne.pdf.

Musiał-Karg, M. (2008). Referendum w państwach europejskich: teoria, praktyka, perspektywy. Toruń: Wydawnictwo Adam Marszałek.

Pastuszka, S.J., \& Machynia, J. (1997). PSL a Konstytucja. Warszawa: Linia.

Piasecki, A.K. (2005). Referenda w III RP. Warszawa: PWN.

Podgórzańska, R. (2004). Ruch Odbudowy Polski. In: K. Kowalczyk, \& J. Sielski (eds.). Polskie partie i ugrupowania parlamentarne (pp. 308-318). Toruń: Wydawnictwo Adam Marszałek.

Projekt Nowej Konstytucji Przeciw Polsce ku dechrystianizacji i rozbiorowi Polski (n.d.). Druk ulotny, luźny.

Referendum konstytucyjne 25 maja 1997 (1997, May). Druk ulotny UW.

Repel, J. (1997). Nowa ustawa o referendum. Przeglą Sejmowy, 2, 22-38.

Rozporzadzenie Krajowej Rady Radiofonii i Telewizji z 13 maja 1994 r.w sprawie trybu postępowania $w$ związku $z$ przedstawianiem $w$ programach publicznej radiofonii i telewizji stanowisk partii politycznych, związków zawodowych i związków pracodawców w węzłowych sprawach publicznych (Dz.U. $1994 \mathrm{nr} 74$, poz. 335).

Rytel-Warzocha, A. (2011). Referendum ogólnokrajowe w państwach Europy ŚrodkowoWschodniej. Warszawa: Wydawnictwo Sejmowe.

Sękowska, E. (1996). Referendum gminne - uregulowania prawne i praktyka. In: M.T. Staszewski, D. \& Waniek (eds.). Referendum $w$ Polsce i Europie Wschodniej (pp. 133-150). Warszawa: ISP PAN.

Siedziako, M. (2018). Bez wyboru: głosowania do Sejmu PRL (1952-1989). Warszawa: Znak.

Sieklucki, D. (2006). Partie lewicy i centrolewicy w polskim systemie partyjnym: aktywność SLD, PSL i UP na polskiej scenie politycznej. Kraków: Wydawnictwo UJ.

Słomka, T. (1997). Ruch Odbudowy Polski - od opcji narodowo-radykalnej do umiarkowanej prawicy. In: S. Gebethner (ed.). Wybory'97: partie i programy wyborcze (pp. 133-150). Warszawa: Elipsa.

Sosnowska-Materska, A. (2006). Socjaldemokracja Rzeczypospolitej Polskiej - dostosowanie syndykatu władzy do zasad demokracji parlamentarnej. Warszawa: Elipsa.

Staszewski, M.T., \& Falski, J.B. (1997). Referendum konstytucyjne - diariusz prac parlamentarnych. In: M. T. Staszewski (ed.). Referendum konstytucyjne w Polsce (pp. 59-90). Warszawa: ISP PAN.

Szamik, J. (2016). Polskie Stronnictwo Ludowe 1990-2005. Warszawa: Muzeum Historii Polskiego Ruchu Ludowego.

Szczepański, D. (2013). Unia Wolności: założenia programowe i działalność (1994-2005). Rzeszów: Wydawnictwo Uniwersytetu Rzeszowskiego.

Szczepański, D. (2014). Unia Demokratyczna, Unia Wolności oraz Partia Demokratyczna demokraci.pl wobec Trzeciej Rzeczypospolitej. In: M. Paździor, \& B. Szmulik (eds.). Instytucjonalne gwarancje zasady pluralizmu politycznego w Polsce na tle standardów europejskich (pp. 385-396). Lublin: Wyższa Szkoła Ekonomii i Innowacji w Lublinie. 
Tomaszewski, W. (2007). Kompromis polityczny w procesie stanowienia Konstytucji Rzeczypospolitej Polskiej z kwietnia 1997 roku. Pułtusk: Akademia Humanistyczna im. Aleksandra Gieysztora.

Uchwała nr 6 Rady Naczelnej PSL w sprawie stanowiska PSL do uchwalonej Konstytucji oraz referendum konstytucyjnego (1997, April). Warszawa.

Uchwała Rady Naczelnej SdRP (1997, April 25). Warszawa.

Uchwała Rady Naczelnej Socjaldemokracji RP (1997, March 1).Warszawa.

Ulicka, G. (1996). Wpływ marketingu politycznego na zmiany w życiu publicznym państw demokratycznych. In: T. Klementewicz (ed.). Trudna sztuka polityki. Szanse, ryzyko, bład. [Studia Politologiczne, 1]. Warszawa: UW.

Urbaniak, K. (1997). Polskie Stronnictwo Ludowe - między rządem a opozycją. In:

S. Gebethner (ed.). Wybory'97: partie i programy wyborcze (pp. 108-132). Warszawa: Elipsa.

Ustawa z dnia 29 czerwca 1995 r. o referendum (Dz.U. 1995 nr 99, poz. 487).

Wąsik, Z. (1997). Prawo nie zabrania. Trybuna, 102. 